\title{
Psychological Approaches to Leaving Religion
}

\author{
Kyle Messick and Miguel Farias
}

\section{$1 \quad$ Introducing Psychological Approaches to Leaving Religion}

Why do some people leave the religion they were brought up in? Are there individual differences between believers and unbelievers? These are some of the questions that have sparked a recent interest in the cognitive, socio-cultural, and neurological study of the non-religious individual. This chapter will summarise and discuss some of these perspectives.

We will use the terms "unbelief" and "unbelievers" as blanket terms to refer to atheists and others who perceive themselves as having no religious belief or affiliation. For the purposes of this chapter, unbelief is defined as an explicit absence or rejection of supernatural belief. There are, of course, different types of unbelievers; one only needs to recall that Socrates was sentenced to death for not believing in the Homeric gods, although he still believed in a metaphysical being that guided the universe. He was only an unbeliever to the culture he found himself in. This chapter focuses on those who do not believe in the existence of any god(s), but this does not mean that these individuals are devoid of other kinds of non-supernatural beliefs, or they may even, at least unconsciously, espouse some kinds of supernatural beliefs.

Psychology is a fractured discipline, where many of its sub-areas are in tension or open disagreement. The study of unbelievers is not an exception, just as it was not for the study of believers either (Ladd and Messick 2016). There have been various proposals about why individuals leave religion or are unbelievers, ranging from the lack of a father figure to a more prominent analytical style of processing information (Vitz 1999; Leuba 1916, Leuba 1934). It is good to remember that there is a history of psychological perspectives which has looked somewhat unfavourably towards religious belief: Freud, for example, famously argued that the image of God worked as an infantile and pre-conscious desire for a father figure (Armstrong 1993). Similarly, ecstatic religious experiences 
such as "oceanic feelings" of merging with the universe were understood as a regression to a pre-personal, early infantile state or, in the case of the experiences of some Christian mystics, such as St Theresa of Avila, these were interpreted as hysterical symptoms (Mazzoni 1996). With hindsight, what is interesting from such psychological perspective is that the default position of a mature individual is understood to be unbelief; a fully grown, autonomous and educated adult, who has explored and understood his or her own psychic history, should be freed of religious belief and longings for any god.

William James (1902) presented a somewhat different, certainly more positive perspective on religion, which has been influential. This influence was probably less due to the scientific merit of James' ideas but to the fact that he captured a cultural mood: religion as an individual experience, not so much a set of beliefs or a set of communal rituals, but a variety of feelings and affects happening to an isolated individual. By framing religion as a natural phenomenon he also, indirectly, inspired subsequent generations of psychological scientists who postulated that to be religious or to believe in religious ideas is not only normal, but the default position of all humans. At the extreme of this position, we find attempts to locate "God" genes or specific brain regions responsible for generating religious-like experiences. A more moderate position considers that we possess a set of cognitive characteristics that bias us towards seeking human or super-human agency in nature, such as anthropomorphism, or that our description of gods is constrained by our way of conceiving intuitive and counter-intuitive abilities so that, for example, a god can walk through walls or on water as these are mildly, but not extremely counter-intuitive actions (Bloom 2007; Boyer 2008; Whitehouse 2016).

A number of studies in the last decade have attempted to show that religious belief is in part the outcome of an intuitive thinking style (for example Shenhav, Rand, and Greene 2012) without noting that other cognitive processing styles can be associated with unbelief (Caldwell-Harris et al. 2011). Cognitive theories that try to establish religious belief as intuitive or "natural" must, however, account for the existence of unbelief. Can cognitive dispositions towards belief be muted or overridden (Gervais and Norenzayan 2012)? One possibility is that one becomes an unbeliever by violating one of various cognitive mechanisms that make us "born believers" (Barret 2012; Norenzayan and Gervais 2013). Thus, we would need to violate: our intuitive mental representations of supernatural agents and our motivation to seek them out as sources of meaning, comfort, and control; further, we would have to resist or break away from the cultural reinforcement for the existence of these supernatural agents and, lastly, to engage in analytical processing instead of accepting our intuitions about these agents. This model is not universally accepted and there are growing criticisms about lack of supporting evidence or contradictory data (Szocik 2018; Lindeman and Svedholm-Häkkinen 2016; van Eyghen 2016 
Caldwell-Harris 2012; Kalkman 2014). One recent study, which calls into question the "naturalness" and "intuitiveness" of belief, consists of a set of three experiments conducted as a field study (in the pilgrimage route to Santiago) in the lab using brain stimulation: it failed to find any significant association between intuitive/analytical processing, or cognitive inhibition, and supernatural belief (Farias, van Mulukom, Kahane, et al. 2017). Instead, the authors suggest that the sociological and anthropological data in support of a socialeducational origin and modulation of belief are more robust than the available cognitive evidence for the naturalness of religion. They also argue that the possibility that some individuals would have to override cognitive dispositions to become unbelievers is a deeply implausible one from an evolutionary perspective, as this would require a very considerable effort with no obvious gains.

From an early age we tend to build relationships with non-physical agents, such as fictional characters, imaginary friends, and religious entities like gods and spirits (Barrett 2012; Boyer 2008). Supernatural agents often have a social role and a place in the upbringing of children, along with ritual practices. Within secular families, though, children are less likely to be exposed to metaphysical agents (Corriveau, Chen, and Harris 2015). It is a kind of truism to affirm that individuals growing up within secular families have never lost a religion - they were simply never socialised into it.

The social psychological literature has examined why some individuals leave or de-convert from their religion. Most de-converts do not necessarily reject their belief in god(s) and thus do not become unbelievers. They may simply change the content of their religious beliefs, as it happens when a Christian becomes a Muslim, or even keep the same beliefs but reject the institutional side of religion, which often entails no longer engaging in religious practices. On the other hand, developing a negative bias towards an established religion can also affect the endorsement of religious beliefs and enactment of rituals (Greer and Francis 1992). An example of this taken from popular culture was the announced break with the Roman Catholic Church by best-selling author Anne Rice, who wrote the Vampire Chronicles series of books. She explained that despite continuing to believe in and follow the teachings of Jesus Christ, her conscience would no longer allow her to be associated with an institution that she perceived as anti-gay and anti-science (Kunhardt 2010). This has been called a "secularizing" or "privatizing exit" - two of six potential forms of de-conversion where an individual moves away from religion altogether or chooses to keep some beliefs and even rituals (Streib 2014). Other types of deconversion actually do not lead the individual towards unbelief but, rather, to adopt a similar or even more conservative system of religious beliefs.

There are then various social and emotional factors that may cause an individual to leave religion: a sudden rejection of God is more likely to be led by emotional factors, whereas a more gradual de-conversion may be rooted in 
intellectual reasons (Hood and Chen 2013). Gradual de-conversion in the USA has been positively associated with a higher level of education (Walters 2010), although the inverse has been reported in different cultural contexts (Lee and Bullivant 2010). One emotional reason for leaving religion, which theologians have considered for a long time and has recently been examined by social psychologists, is anger towards God (Exline, Crystal, Smyth, and Carey 2011).

Leaving religion generally involves a combination of four social and emotional domains: (1) intellectual doubt or denial about the truth of a belief system; (2) moral criticism: rejection of an entire way of life of a religious group; (3) emotional suffering: grief, guilt, loneliness, despair; and (4) disaffiliation from the community (Barbour 1994). In addition to socio-emotional factors, there are some indications that personality may also play a role in deconversion (Streib et al. 2011). In US and German samples, de-converts were found to have lower levels of religious fundamentalism and right-wing authoritarianism, as well as higher levels of openness to experience - when compared to their religious peers.

Particularly in countries dominated by religious traditions, leaving religion can have important personal consequences. US de-converts have reported to experience negative social, existential, and career consequences, while justifying their resolution in moving away from what they perceive as a "rigid and oppressive way of life" (Marriott 2015). Although they report prejudice and discrimination, they also report greater well-being after converting to unbelief (Doane and Elliot 2015). There is growing evidence that unbelievers are some of the least liked people in areas of the world with religious majorities (Gervais, Shariff, and Norenzayan 2011). For further non-European examples, see Schirmacher's chapter.

Neuroscience studies suggest that there might be biological factors associated with unbelief. It has been argued that the dopamine system and the frontal lobes play important roles in the generation of religious belief (McNamara, Durso, Brown, and Harris 2009) — but what accounts for unbelief? Whereas most studies deal with healthy individuals, the literature investigating neurological deficits presents interesting insights concerning the biological processes of unbelief. One study, which included an assessment of beliefs before and after brain surgery, found that the cerebrum was associated with religiosity levels of participants. The cerebrum is known to be involved in movement, sensory processing, language, learning, and memory. In this study, it was found that individuals with anterior cortical lesions (front of the cerebrum) were less religious than those with posterior lesions (back of the cerebrum; Urgesi, Aglioti, Skrap, and Fabbro 2010). In other words, some areas of the brain seem to play a role in deciding if an individual holds stronger religious beliefs. 
Further evidence from lesion studies shows that among patients with dementia within the frontal and temporal lobes, and in those with Parkinson's disease, the changes that occur in the frontotemporal lobe can be associated with a loss of interest in religion and a simultaneous decrease in the neurotransmitter dopamine.

The frontal lobes seem to play an active role in religious practices (Johnstone et al. 2012), and alterations of brain frontal functions have been shown to result in an increase or decrease of religious belief (Devinsky and Lai 2008; Mendez, Lauterbach, and Sampson 2008). One neurobiological theory of belief and unbelief argues that the prefrontal cortex is critical for doubt processing, so that damage to the prefrontal cortex would result in less doubt and a higher probability of increased religiosity (Asp, Ramchandran, and Tranel 2012). They hypothesize that those with a doubt-deficit will be more religious, whereas the less religious would have a higher doubt-processing capacity. One small study showed that patients with damage to the prefrontal cortex had an increase in religiosity and a correspondent decrease in doubt processing, when compared to non-patients. The authors further suggest that there is a neurodevelopmental basis for this theory: religious beliefs are generally strong in children, but with adolescence there is increased growth in the prefrontal cortex and of doubt processing, and adolescence is known to be a period when many report to lose their religion temporarily or for good (Asp and Tranel 2013).

Other studies have focused on the role of the medial prefrontal cortex (part of the frontal lobe) in relation to religious belief and unbelief, as this brain area is known to regulate self-reflection, compliance to social norms, error detection, and theory of mind - all these potentially being cognitive prerequisites to religious belief (Muramato 2004). Thus, strong religiosity would result from a hyper-activation of the medial prefrontal cortex, whereas an underperforming medial prefrontal cortex could result in an absence of religious ideas. The underlying hypothesis is that unbelievers would show lower levels of self-reflection and endorsement of cultural norms, error detection, and theory of mind. One brain imaging study on religious belief and pain processing has showed that unbelievers show a lower activation of the ventromedial pre-frontal cortex, a specific part of the prefrontal cortex, when compared to religious individuals while looking at a religious-themed image (Wiech, Farias, Kahane, et al. 2009); however, this was explained by a process of emotional reappraisal of the pain by religious individuals, and it's not reasonable to suggest that, overall, unbelievers would have lower levels of activation of the medial pre-frontal cortex.

Dopamine-rich midbrain regions have also been associated with shifts in belief and belief formation (Schmack et al. 2015; Schwartenbeck, FitzGerald, and 


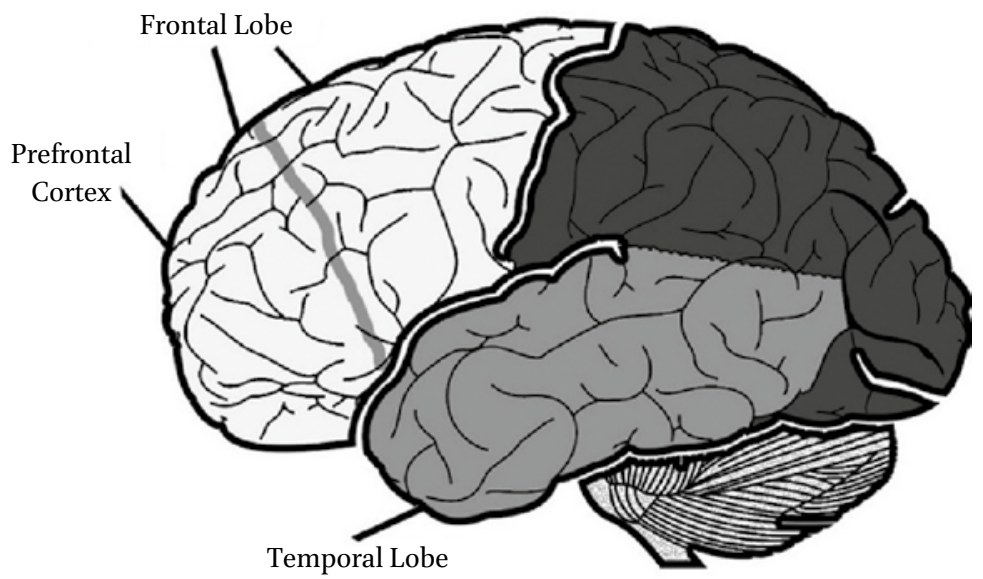

FIGURE 25.1 There is increasing evidence that numerous areas of the brain influence unbelief

Dolan 2016), as with religious belief and rituals (Perroud 2009). As increased availability of dopamine increases religious belief, the opposite has been found for a deficit of dopamine, such is the case with Parkinson's patients, who show a dopamine deficiency and lower levels of religiosity (Harris and McNamara 2009). Further, particular types of Parkinson's disease seem to differentially affect religious ideation; for example, left-onset Parkinson's patients experience a severe inability to activate religious concepts and accessing aesthetic-based religious cognition (Butler et al., 2011 Butler, McNamara, and Durso 2010), while patients with right-onset Parkinson's showed greater difficulty accessing ritualbased religious cognition (Butler, McNamara, and Durso 2011).

Although this body of work provides some evidence that religious unbelief is associated with or underpinned by biological variables, the findings are very preliminary, showing ambiguous or even contradictory results. For example, concerning the role of dopamine in the increase of unbelief, it has been suggested that religious practices may decrease with Parkinson's onset, but qualitative data show that religion and spirituality are still regarded as important by these patients (Redfern and Coles 2015; Edwards et al. 1997). In addition to conflicting findings, there are also shortcomings in the literature in relation to how religiosity is defined and measured.

Some psychologists have argued that leaving religion is counterintuitive or a sub-optimal strategy, as subjective well-being is apparently higher among religious people (Hayward et al. 2016; Aghababaei 2014; Aghababaei et al. 2016; though see Horning et al. 2011). However, recent research has found that 
well-being is associated with certainty of belief, so that people with a higher certainty in their religious beliefs or unbelief report higher levels of well-being (Galen and Kloet 2011). Additionally, religious beliefs are associated with satisfaction in life (Ellison 1991; Pollner 1989), happiness (Myers and Diener 1996), and coping with the death of a loved one (Palmer and Noble 1986) and difficult life events (McIntosh et al. 1993). But these effects largely disappear when controlling for a variety of life circumstances, particularly societal factors that regulate the satisfaction of basic needs (food, health, housing; see Maslow 1943). In more affluent societies, levels of subjective well-being are similar among believers and unbelievers (Diener 2011). Subjective well-being is further boosted in unbelievers when the level of social engagement and embeddedness are high, similarly to what has been found for religious believers with high levels of communal involvement (Galen 2015).

Evidence from experimental social psychology indicates that unbelievers might cling on to belief systems based on the intrinsic value of science or ideas of humanity's moral progress (Farias, Newheiser, Kahane, and de Toledo 2013; Rutjens, van Harreveld, and van der Pligt 2010; Rutjens et al. 2016). These unbelievers would find in such secular ideas the same kind of cognitive-emotive comfort that religious believers do, by using secular explanations to provide meaning and order in their lives (Stavrova, Ehlebracht, and Fetchenhauer 2016). One possibility is that within growing secular societies individuals will find other non-religious sources of existential meaning that provide them with psychological comfort and well-being. To what an extent these non-religious sources engage the same kind of psychological processes as religious beliefs in regard to meaning-making is still an open question.

\section{3}

\section{Methodological Perspectives and Turning Points}

Above we have highlighted different theoretical approaches which rely on various methods, from social psychological experiments using self-report measures to brain-imaging and lesion studies. Table 1 gives examples of some of the key methods used by the various domains of the study of unbelief. Note that there are potential overlaps between some of these domains; for example, cognitive studies of religion sometimes use paradigms that are very common in experimental social psychology (for example various priming studies in Gervais and Norenzayan 2012).

The recent focus on unbelief clearly follows contemporary trends that emphasize cognitive, evolutionary, and biological perspectives instead of, 
TABLE 25.1 Examples of Methodological Approaches to the Study of Unbelief

\begin{tabular}{|c|c|c|c|}
\hline Cognitive & $\begin{array}{l}\text { Social- } \\
\text { Psychological }\end{array}$ & Biological & $\begin{array}{l}\text { Well-being } \\
\text { and Meaning }\end{array}$ \\
\hline $\begin{array}{l}\text { Priming experiments } \\
\text { using tests of } \\
\text { intuitive and } \\
\text { analytical thinking } \\
\text { with self-report } \\
\text { measures of religious } \\
\text { belief(Gervais and } \\
\text { Norenzayan 2012) }\end{array}$ & $\begin{array}{l}\text { Field and lab } \\
\text { experiments that } \\
\text { manipulate stress } \\
\text { and existential } \\
\text { anxiety with self- } \\
\text { report measure of } \\
\text { belief in science } \\
\text { (Farias, Newheiser, } \\
\text { Kahane, and Toledo } \\
\text { 2013) }\end{array}$ & $\begin{array}{l}\text { Brain lesion study } \\
\text { with self-report } \\
\text { measure of } \\
\text { spirituality(Urgesi, } \\
\text { Aglioti, Skrap, and } \\
\text { Fabbro 2010) }\end{array}$ & $\begin{array}{l}\text { Large sample } \\
\text { surveys of well- } \\
\text { being, socio- } \\
\text { economical status, } \\
\text { and levels of } \\
\text { religiosity(Diener, } \\
\text { Tay, and Myers } \\
(2011)\end{array}$ \\
\hline $\begin{array}{l}\text { Survey using tests } \\
\text { of intuitive and } \\
\text { analytical thinking } \\
\text { with self-report } \\
\text { measures of religious } \\
\text { belief (Shenhav, } \\
\text { Rand, and Greene } \\
2012 \text { ) }\end{array}$ & $\begin{array}{l}\text { Bereaved and } \\
\text { cancer patient } \\
\text { samples with self- } \\
\text { report measures of } \\
\text { religiosity and anger } \\
\text { towards God(Exline, } \\
\text { Crystal, Smyth, and } \\
\text { Carey 2011) }\end{array}$ & $\begin{array}{l}\text { Double-blind brain } \\
\text { stimulation study } \\
\text { of the right inferior } \\
\text { frontal gyrus using } \\
\text { implicit tests of } \\
\text { supernatural belief } \\
\text { (Farias et al. 2017) }\end{array}$ & $\begin{array}{l}\text { Nationally } \\
\text { representative } \\
\text { sample with } \\
\text { measures of } \\
\text { personal control, } \\
\text { life satisfaction, } \\
\text { and belief in } \\
\text { scientific progress } \\
\text { (Stavrova, } \\
\text { Ehlebracht, and } \\
\text { Fetchenhauer } \\
\text { 2016). }\end{array}$ \\
\hline
\end{tabular}

say, developmental perspectives. There have also been some attempts at categorising unbelievers through the development of empirical-based typologies (Schnell 2015; Silver et al. 2014). Despite the interest and expansion of this literature, it is hard to pinpoint any particular methodological turning points with one exception: the attempt to understand and measure unbelief as a positive phenomenon, instead of as simply the absence or low levels of belief, as BeitHallami (Martin 2006) proposed in one of the early writings on this subject. This turn has led researchers to not only propose typologies of unbelievers but to map out potential kinds of unbelief, such as Humanism, Science, Progress, and Existentialism. 
Much work on religion and unbelief is likely to suffer from personal biases as researchers lean towards or against religious belief. One cannot forget that much of the research in the psychology of religion and health has been inextricably associated with an US-based agenda to promote religion as a source of physical and mental health. Conversely, there have been efforts by North American researchers to promote the idea that unbelievers are more analytical or reflective than believers (Pennycook, Ross, Koehler, and Fugelsang 2016).

These personal biases are inscribed in historical processes which psychologists tend to overlook. For example, cognitive theories that claim religious belief to be innate reflect an earlier historical understanding of belief as being God-given (Brooke 1991), which means that those who are not believers are either acting against God, or against their human nature (Barrett and Church 2013). It is curious that cognitive theories of religion are partly regurgitating this innateness idea, but using updated concepts and methods, instead of studying unbelief in its own right.

It is also unclear how much psychological variables can contribute to explaining the emergence of unbelief, after taking into account broader sociocultural and educational factors (Banerjee and Bloom 2013; Voas and MacAndrew 2012; Willard and Cingl 2017). Understanding these broader variables is also crucial for the purpose of definition and categorisation. A variety of partly overlapping terms such as "non-religious," "nones," and "atheists" are used in the field, but there has been little effort in attempting to clarify and refine these concepts (Conrad 2018; Lee 2014).

Unlike sociology and anthropology, psychology has never formulated specific theories for religious belief and is unlikely to do it for unbelief. Psychology has considered that religious belief is underpinned by or associated with general developmental, cognitive, and social-psychological processes. Probably the most enduring and successful psychological explanatory efforts have been functionalist - how does religious belief and practices help individuals to cope with adversity, uncertainty, fear or to make sense of our lives? It is likely that the study of unbelief will follow a similar route in looking at how various forms of unbelief fulfil psychological functions or motivational needs.

There are two exciting things about the study of unbelief: one is the novelty of the field concomitant with large national surveys showing the growth of 
unbelievers; the second is its interdisciplinary nature. Recent journals and organisations such as the journal Secularism and NonReligion and the NonReligion and Secularity Research Network (NSRN) feature articles from various disciplinary fields, including psychology, sociology, anthropology, religious studies and cultural studies. There is a very clear awareness of the need to understand where each particular field is coming from, including methodologically. This has led to the development of contributions focusing on various methods to studying unbelief, from the use of brain stimulation and implicit association tests to large-scale surveys and interviews. ${ }^{1}$ This is an excellent example of how a field can grow benefitting from the insights of other disciplines.

The rapid pace at which non-religion studies are expanding means that it needs to pay closer attention to terminology and definition (Lee 2012), as well as adapting methods for different cultural settings (Sevinç, Coleman III, and Hood 2018). With so many different types of unbelievers and cultural differences among those in different areas of the world, it is hard to find definitions apply easily across countries. One recent ongoing effort to advance the field and terminological concerns is a large cross-cultural and interdisciplinary project on mapping unbelief, which include large and small grants with over 40 participating research groups worldwide. ${ }^{2}$ This programme of research will advance our understanding of the kinds of unbelief we can find, who are the unbelievers regarding socio-demographic characteristics, and also explore the alternative meaning-making systems available to individuals growing without belief or who have left their religious beliefs behind.

We have started this part by stating that there are two exciting things about the study of unbelief: its novelty and its interdisciplinary nature. There is a third less acknowledged factor though, which is a real potential to demolish and reconstruct how we have to come to understand religion and religious belief in particular. Recent cognitive and evolutionary approaches to religion have been criticised for neglecting or distorting historical and anthropological records showing the existence of unbelief in Ancient India and Greece, and in small pre-literate societies (Brazil and Farias 2016). The developing study of unbelief has the potential to very quickly change or obliterate the field of cognitive science of religion, with its key assumptions of the naturalness or innateness of religious belief. It may be the case that as the study of unbelief advances, in a decade or two many of the current cognitive assumptions on religious belief will be regarded no differently from ninetheenth century theories suggesting that Mars and Venus were populated by human-like societies.

1 https://nsrn.net/2016/04/27/blog-series-research-methods-for-the-scientific-study-of-nonre ligion/ Accessed 25/02/2019.

2 https://research.kent.ac.uk/understandingunbelief/ Accessed 25/02/2019. 


\section{References}

Aghababaei, N. 2014. "God, the Good Life, and HEXACO: The Relations Among Religion, Subjective Well-being and Personality." Mental Health, Religion \& Culture. $17(3), 284-290$.

Aghababaei, N., Sohrabi, F., Eskandari, H., Borjali, A., Farrokhi, N., and Chen, Z.J. 2016. "Predicting Subjective Well-being by Religious and Scientific Attitudes with Hope, Purpose in Life, and Death Anxiety as Mediators." Personality and Individual Differences. 90, 93-98.

Armstrong, K. 1993. A History of God: The 40oo-Year Quest of Judaism, Christianity, and Islam. New York: Alfred A.

Asp, E., Ramchandran, K., and Tranel, D. 2012. "Authoritarianism, Religious Fundamentalism, and the Human Prefrontal Cortex." Neuropsychology. 26:4, 414.

Asp, E., and Tranel, D. 2013. "False Tagging Theory." In D.T. Stuss, and R.T. Knight, eds, Principles of Frontal Lobe Function. Oxford University Press, 383.

Banerjee, K., and Bloom, P. 2013. "Would Tarzan Believe in God? Conditions for the Emergence of Religious Belief." Trends in Cognitive Sciences. 17:1, 7-8.

Barbour, J.D. 1994. Versions of Deconversion. Autobiography and the Loss of Faith. Charlottesville: Univ. Press of Virginia.

Barrett, J.L., and Church, I.M. 2013. "Should CSR Give Atheists Epistemic Assurance? On Beer-Goggles, BFFs, and Skepticism Regarding Religious Beliefs." The Monist. 96:3, 311-324.

Barrett, J.L. 2012. Born Believers: The Science of Children's Religious Belief. Simon and Schuster.

Bloom, P. 2007. "Religion is Natural." Developmental Science. 10:1, 147-151.

Boyer, P. 2008. "Being human: Religion: Bound to Believe?" Nature. 455:7216, 1038-1039.

Brazil, I.A. and Farias, M. 2016. "Why Would Anyone Want to Believe in Big Gods?" Behavioral and Brain Sciences. 39, 24-25.

Brooke, J.H. 1991. Science and Religion: Some Historical Perspectives. Cambridge University Press.

Butler, P.M., McNamara, P., and Durso, R. 2010. "Deficits in the Automatic Activation of Religious Concepts in Patients with Parkinson's Disease." Journal of the International Neuropsychological Society. 16:2, 252-261.

Butler, P.M., McNamara, P., and Durso, R. 2011. "Side of Onset in Parkinson's Disease and Alterations in Religiosity: Novel Behavioral Phenotypes." Behavioural Neurology. 24:2, 133-141.

Butler, P.M., McNamara, P., Ghofrani, J., and Durso, R. 2011. "Disease-associated Differences in Religious Cognition in Patients with Parkinson's Disease." Journal of Clinical and Experimental Neuropsychology. 33(8), 917-928.

Caldwell-Harris, C.L. 2012. "Understanding Atheism/Non-belief as an Expected Individual-Differences Variable." Religion, Brain \& Behavior. 2:1, 4-23. 
Caldwell-Harris, C., Murphy, C.F., Velazquez, T., and McNamara, P. 2011. "Religious Belief Systems of Persons with High Functioning Autism." Proceedings of the Annual Meeting of Cognitive Science Society, 33.

Conrad, N.G. 2018. "An Argument for Unbelief: A Discussion about Terminology." Secularism and Nonreligion. 7:1, 11.

Corriveau, K.H., Chen, E.E., and Harris, P.L. 2015. "Judgments About Fact and Fiction by Children from Religious and Nonreligious Backgrounds." Cognitive Science. 39:2, $353-382$.

Devinsky, O., and Lai, G. 2008. "Spirituality and Religion in Epilepsy." Epilepsy \& Behavior. 12:4, 636-643.

Diener, E., Tay, L., and Myers, D.G. 2011. “The Religion Paradox: If Religion Makes People Happy, Why are So Many Dropping Out?" Journal of Personality And Social Psychology. 101:6, 1278-1290.

Doane, M.J., and Elliott, M. 2015. "Perceptions of Discrimination Among Atheists: Consequences for Atheist Identification, Psychological and Physical Well-being." Psychology of Religion and Spirituality. 7:2, 130.

Edwards-Lee, T., Miller, B.L., Benson, D.F., Cummings, J.L., Russell, G.L., Boone, K., and Mena, I. 1997. "The Temporal Variant of Frontotemporal Dementia." Brain. 120:6, 1027-1040.

Ellison, C.G. 1991. "Religious Involvement and Subjective Well-Being." Journal of Health and Social Behavior, 80-99.

Exline, J.J.; Park, C.L.; Smyth, J.M.; and Carey, M.P. 2011. "Anger Toward God: SocialCognitive Predictors, Prevalence, and Links with Adjustment to Bereavement and Cancer." Journal of Personality and Social Psychology, 100: 129-148.

Farias, M., van Mulukom, V., Kahane, G. Kreplin, U., Joyce, A., Soares, P., Oviedo, L., Hernu, M., Rokita, K., Savulescu, J., and Möttönen, R. Mottonen, R. 2017. "Supernatural Belief is not Modulated by Intuitive Thinking Style or Cognitive Inhibition." Scientific Reports. 7:1, 15100.

Farias, M. 2013. "The Psychology of Atheism." In S. Bullivant, and M. Ruse, eds, The $O x$ ford Handbook of Atheism. Oxford: Oxford University Press, 468-482.

Farias, M., Newheiser, A., Kahane, G., and de Toledo, Z. 2013. "Scientific Faith: Belief in Science Increases in the Face of Stress and Anxiety." Journal of Experimental Social Psychology. 49:6, 1210-1213.

Galen, L.W. 2015. "Atheism, Wellbeing, and the Wager: Why Not Believing in God (with Others) is Good for You." Science, Religion, and Culture. 2(3), 54-69.

Galen, L.W. and J.D. Kloet 2011. "Mental Well-Being in the Religious and the Non-Religious: Evidence for a Curvilinear Relationship." Mental Health, Religion \& Culture. 14:7:673-689.

Gervais, W.M. and Norenzayan, A. 2012. "Analytic Thinking Promotes Religious Disbelief." Science. 336:6o80, 493-496. 
Gervais, W.M., Shariff, A.F., and Norenzayan, A. 2011. "Do You Believe in Atheists? Distrust is Central to Anti-atheist Prejudice." Journal of Personality and Social Psychology. 101:6, 1189 .

Greer J., and Francis, L.J. 1992. "Measuring 'Rejection of Christianity' Among 14 to 16-Year-Old Adolescents in Catholic and Protestant Schools in Northern Ireland." Personality and Individual Differences. 13:12, 1345-1348.

Harris, E., and McNamara, P. 20o9. "Neurologic Constraints on Evolutionary Theories of Religion." In E. Voland, and W. Schiefenhövel, eds, The Biological Evolution of Religious Mind and Behavior. Springer Berlin Heidelberg, 205-215.

Hayward, R.D., Krause, N., Ironson, G., Hill, P.C., and Emmons, R. 2016. "Health and WellBeing Among the Non-Religious: Atheists, Agnostics, and No Preference Compared with Religious Group Members.” Journal of Religion and Health. 55:3, 1024-1037.

Hood Jr, R.W., and Chen, Z. 2013. "Conversion and Deconversion." In S. Bullivant, and M. Ruse, eds, Oxford Handbook of Atheism. Oxford: Oxford University Press, 537-549.

Horning, S.M., Davis, H.P., Stirrat, M., and Cornwell, R.E. 2011. "Atheistic, Agnostic, and Religious Older Adults on Well-Being and Coping Behaviors." Journal of Aging Studies. 25:2, 177-188.

James, W., 1902. The Varieties of Religious Experience. NY: Penguin Books.

Johnstone, B., Bodling, A., Cohen, D., Christ, S.E., and Wegrzyn, A. 2012. "Right Parietal Lobe-Related "Selflessness" as the Neuropsychological Basis of Spiritual Transcendence." International Journal for the Psychology of Religion. 22:4, 267-284.

Kalkman, D.P. 2014. "Three Cognitive Routes to Atheism: a Dual-Process Account." Religion. 44:1, 72-83.

Keysar, A., and Navarro-Rivera, J. 2013. "A World of Atheism: Global Demographics." In S. Bullivant, and M. Ruse, eds, The Oxford Handbook of Atheism. Oxford: Oxford University Press, 553-586.

Kirkpatrick, L.A., and Shaver, P.R. 1990. "Attachment Theory and Religion: Childhood Attachments, Religious Beliefs, and Conversion." Journal for the Scientific Study of Religion 315-334.

Koenig, H.G., McCullough, M.E., and Larson, D.B. 2001. Handbook of Religion and Health. Oxford University Press.

Kunhardt, J. 2010. (July 29.) “Anne Rice: 'I Quit Being A Christian.” The Huffington Post. At https://www.huffpost.com/entry/anne-rice-i-quit-being-a_n_663915. Accessed $1 / 7 / 2012$.

Ladd, K.L., and Messick, K.J. 2016. "A Brief History of the Psychological Study of the Role(s) of Religion.” In W. Woody, R. Miller, and W. Wozniak, eds, Psychological Specialties in Historical Context: Enriching the Classroom Experience for Teachers and Students. Washington DC: Society for the Teaching of Psychology, Division 2, American Psychological Association, 204-216. Retrieved from https://teachpsych .org/ebooks/psychspec. 
Leuba, J.H. 1916. “The Belief in God and Immortality." Boston: Sherman, French.

Leuba, J.H. 1934. "Religious Beliefs of American Scientists." Harper's Magazine. 169, 291-300.

Lee, L. 2012. "Research Note: Talking About a Revolution: Terminology for the New Field of Non-religion Studies." Journal of Contemporary Religion. 27:1, 129-139.

Lee, L. 2014. "Secular or Nonreligious? Investigating and Interpreting Generic 'Not Religious' Categories and Populations." Religion. 44:3, 466-482.

Lee, L., and Bullivant, S. 2010. "Where Do Atheists Come From?" New Scientist. 205:2750, 26-27.

Lindeman, M., and Svedholm-Häkkinen, A.M. 2016. "Let Us Be Careful with the Evidence on Mentalizing, Cognitive Biases, and Religious Beliefs." Behavioral and Brain Sciences. 39, e18.

Manning, C. 2009. "Atheism, Secularity, the Family, and Children." Atheism and Secularity. 1, 19-42.

Marriott, R.J. 2015. The Cost of Freedom: A Grounded Theory Study on the Impact of Deconversion from Christianity to Atheism. Biola University.

Martin, M. ed. 2006. The Cambridge Companion to Atheism. Cambridge University Press.

Maslow, A.H. 1943. "A Theory of Human Motivation." Psychological Review. 50:4, 370.

Mazzoni, C. 1996. Saint Hysteria: Neurosis, Mysticism and Gender in European Culture. Cornell University Press, 37.

McIntosh, D.N., Silver, R.C., and Wortman, C.B. 1993. "Religion's Role in Adjustment to a Negative Life Event: Coping with the Loss of a Child." Journal of Personality and Social Psychology. 65:4, 812.

McNamara, P., Durso, R., Brown, A., and Harris, E. 2006. "The Chemistry of Religiosity: Evidence from Patients with Parkinson's Disease." In P. McNamara, ed, Where God and Science Meet: How Brain and Evolutionary Studies Alter Our Understanding of Religion, Volume II: The Neurology of Religious Experience. Westport: Praeger, 1-14.

Mendez, M.F., Lauterbach, E.C., and Sampson, S.M. 2008. "An Evidence-Based Review of the Psychopathology of Frontotemporal Dementia: a Report of the ANPA Committee on Research." The Journal of Neuropsychiatry and Clinical Neurosciences. 20:2, 130-149.

Muramoto, O. 2004. "The Role of the Medial Prefrontal Cortex in Human Religious Activity." Medical Hypotheses. 62:4, 479-485.

Myers, D.G., and Diener, E. 1996. "The Pursuit of Happiness." Scientific American. 274:5, $70-72$.

Norenzayan, A., and Gervais, W.M. 2013. "The Origins of Religious Disbelief." Trends in Cognitive Sciences. 17:1, 20-25.

Palmer, C.E., and Noble, D.N. 1986. "Premature Death: Dilemmas of Infant Mortality." Social Casework. 67:6, 332-339. 
Pennycook, G., Ross, R.M., Koehler, D.J. and Fugelsang, J.A. 2016. "Atheists and Agnostics Are More Reflective than Religious Believers: Four Empirical Studies and a Meta-Analysis," PLoS One: 11:4.

Perroud, N., Huguelet, P., and Koenig, H.G. 2009. "Religion/Spirituality and Neuropsychiatry." In P. Huguelet, and H.G. Koenig, eds, Religion and Spirituality in Psychiatry. Cambridge: Cambridge University Press, 48-64.

Phillips, A. 2015. "The Resurrection of Self: How Deconversion from Religious Belief to Atheism Healed a History of Rejection, Trauma, and Shame" Doctoral dissertation. State University of New York at Stony Brook.

Pollner, M. 1989. "Divine Relations, Social Relations, and Well-Being." Journal of Health and Social Behavior. 30:1, 92-104.

Redfern, C., and Coles, A. 2015. "Parkinson's Disease, Religion, and Spirituality." Movement Disorders Clinical Practice. 2:4, 341-346.

Rutjens, B.T., van Harreveld, F., van der Pligt, J., van Elk, M., and Pyszczynski, T. 2016. "A March to a Better World? Religiosity and the Existential Function of Belief in SocialMoral Progress." The International Journal for the Psychology of Religion. 26:1, 1-18.

Rutjens, B.T., van Harreveld, F., and van der Pligt, J. 2010. "Yes We Can: Belief in Progress as Compensatory Control." Social Psychological and Personality Science. 1:3, 246-252.

Schmack, K., Rössler, H., Sekutowicz, M., Brandl, E.J., Müller, D.J., Petrovic, P., and Sterzer, P. 2015. "Linking Unfounded Beliefs to Genetic Dopamine Availability." Frontiers in Human Neuroscience. 9.

Schnell, T. 2015. "Dimensions of Secularity (DoS): An Open Inventory to Measure Facets of Secular Identities." The International Journal for the Psychology of Religion. 25:4, 272-292.

Schwartenbeck, P., FitzGerald, T.H., and Dolan, R. 2016. "Neural Signals Encoding Shifts in Beliefs." NeuroImage. 125, 578-586.

Sevinç, K., Coleman III, T.J., and Hood Jr, R.W. 2018. "Non-Belief: An Islamic Perspective." Secularism and Nonreligion. 7:1.

Shenhav, A., Rand, D.G. and Greene, J.D. 2012. "Divine Intuition: Cognitive Style Influences Belief in God." Journal of Experimental Psychology: General. 141, 423-428.

Silver, C.F., Coleman III, T.J., Hood Jr, R.W., and Holcombe, J.M. 2014. "The Six Types of Nonbelief: a Qualitative and Quantitative Study of Type and Narrative." Mental Health, Religion \& Culture. 17:10, 990-1001.

Stavrova, O., Ehlebracht, D., and Fetchenhauer, D. 2016. "Belief in ScientificTechnological Progress and Life Satisfaction: The Role of Personal Control." Personality and Individual Differences. 96, 227-236.

Streib, H. 2014. "Deconversion." The Oxford Handbook on Religious Conversion. Oxford: Oxford University Press.

Streib, H., Silver, C.F., Csöff, R.M., Keller, B., and Hood, R.W. 2011. Deconversion: Qualitative and Quantitative Results from Cross-cultural Research in Germany and the United States of America (Vol. 5). Vandenhoeck and Ruprecht. 
Streib, H., and Keller, B. 2004. "The Variety of Deconversion Experiences: Contours of a Concept in Respect to Empirical Research." Archive for the Psychology of Religion. 26:1, 181-200.

Szocik, K. 2018. "Adaptationist Accounts Can Tell Us More About Religion than Cognitive Accounts Can." In H. van Eyghen, R. Peels, and G. van den Brink, eds, New Developments in the Cognitive Science of Religion: The Rationality of Religious Belief. Cham: Springer, 93-108.

Tay, L., Li, M., Myers, D., and Diener, E. 2014. "Religiosity and Subjective Well-being: An International Perspective.” In L. Tay, and D. Myers, eds, Religion and Spirituality Across Cultures. Cham: Springer, 163-175.

Urgesi, C., Aglioti, S.M., Skrap, M., and Fabbro, F. 2010. "The Spiritual Brain: Selective Cortical Lesions Modulate Human Self-Transcendence." Neuron. 65:3, 309-319.

van Eyghen, H. 2016. "Religious Belief is Not Natural. Why Cognitive Science of Religion Does Not Show That Religious Belief is Trustworthy." Studia Humana. 5, 4.

Vitz, P.C. 1999. Faith of the Fatherless: The Psychology of Atheism. San Fransisco: Ignatius Press.

Voas, D. and McAndrew, S. 2012. "Three Puzzles of Non-religion in Britain." Journal of Contemporary Religion. 27, 29-48.

Walters, K. 2010. Atheism: A Guide for the Perplexed. London: Bloomsbury Publishing.

Wiech, K., Farias, M., Kahane, G., Shackel, N., Tiede, W., and Tracey, I. 2009. "An fMRI Study Measuring Analgesia Enhanced by Religion as a Belief System." PAIN. 139:2, 467-476.

Whitehouse, H. 2016. "Cognitive Evolution and Religion: Cognition and Religious Evolution." Issues in Ethnology and Anthropology. 3:3, 35-47.

Willard, A.K. and Cingl, L. 2017. "Testing Theories of Secularization and Religious Belief in the Czech Republic and Slovakia." Evolution and Human Behavior. Evolution and Human Behavior. 38:5: 604-615.

Wilson, D.S. 2005. "Testing Major Evolutionary Hypotheses About Religion with a Random Sample." Human Nature: An Interdisciplinary Biosocial Perspective. 16:4, 382.

Zuckerman, P. 2009. "Atheism, Secularity, and Well-Being: How the Findings of Social Science Counter Negative Stereotypes and Assumptions." Sociology Compass. 3:6, 949-971.

Zuckerman, P. 2007. Atheism: Contemporary Numbers and Patterns. Cambridge: Cambridge University Press. 